\section{Emerging Private Universities in Bangladesh: Public Enemy or Ally?}

\section{Richard Hopper}

Richard Hopper is a doctoral candidate at the Harvard University Graduate School of Education. Address: HGSE Department of Administration, Planning and Social Policy, 409 Longfellow Hall, Appian Way, Harvard University, Cambridge, MA 02138 USA. E-mail: <hopperri@hugse1.harvard.edu>.

$\mathrm{T}$ he emergence of private universities in Bangladesh began with the enactment of a series of laws governing higher education in 1992. In just five years these nongovernmental institutions have become a pervasive part of the academic landscape, satisfying the soaring demand for higher education and presenting new challenges for a troubled public system. The current state of private universities in Bangladesh, however, suggests that these initiatives may complement more than they threaten the traditional publicly financed system.

Bangladesh's image of poverty and natural disasters seems a world away from the air-conditioned computer lab at the private North South University (NSU) in Dhaka. Here undergraduate students of business administrationin spite of the crowded squalor on the streets below-work at computer terminals with Pentium processors and laser printers. The 1,600 students at NSU also enjoy a spacious library with a surprising array of textbooks, scholarly journals, and periodicals. Several hundred miles to the south in the city of Chittagong, 3 of the 625 medical students at the private University of Science and Technology, Chittagong (USTC) assist in an emergency hysterectomy in the fifthfloor operating room of their 250-bed teaching hospital, while a group of classmates dissects a human cadaver in the school's anatomy lab.

\section{Bangladesh's image of poverty and natural disasters seems a world away from the air-conditioned computer lab at the private North South University (NSU) in Dhaka.}

These new learning environments are now possible thanks to the Non-Governmental Universities Act of 1992, which has permitted the establishment of private universities in Bangladesh. Until 1992, Bangladesh had a purely public system of eight universities that could accommodate a limited number of eligible aspirants, disappointing about 75 percent of the nearly 80,000 who applied for admission. This forced many affluent Bangladeshis to seek university degrees abroad in places such as India and the United States, while others pursued the limited alternatives at home or entered into the local labor force without a degree.

Further compounding the problem of surplus demand for higher education is a climate of violence on the public university campuses, where political parties have maintained a stronghold by arming student groups since the country's independence in 1971. Violence at public universities in Bangladesh claims many student lives each year, and causes countless unscheduled closures or "session jams," sometimes preventing class meetings for more than 100 days per year. The result: at the foremost Dhaka University, a three-year honors degree takes an average of six years to complete. In contrast, the private universities have never experienced an unscheduled closure due to unrest and students are proceeding through private degree programs without delay.

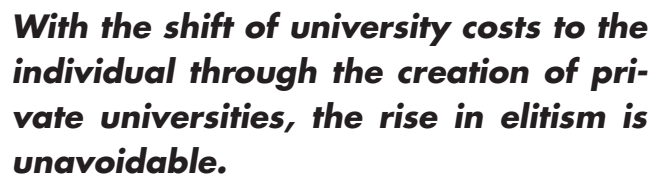

With the shift of university costs to the individual through the creation of private universities, the rise in elitism is unavoidable.

Since the passage of the 1992 Act, no fewer than 16 private universities have opened: 13 in Dhaka, 2 in Chittagong, and 1 in Comilla. In a country where the average per capita income is estimated to be $\$ 277$ per year and where public universities are nearly free, the tuition fees charged by the new private institutions are simply astronomical. The most expensive of the private universities is the Independent University of Bangladesh (IUB), located in the wealthy Baridhara district of Dhaka-home to successful industrialists and expatriate families. The annual tuition and fees at IUB are nearly $\$ 5,000$; NSU is not far behind. In contrast, another private institution, Central Women's University, charges an annual tuition of about \$500 for each of its 88 students, but lacks a computer laboratory, library holdings, and air conditioning. The majority of private universities, however, are priced for the growing upper middle class with tuition rates between $\$ 1,000$ and $\$ 2,000$.

With the shift of university costs to the individual through the creation of private universities, the rise in elitism is unavoidable. Yet, many Bangladeshis are content with this new phenomenon, believing that the benefits of higher education accrue to the individual rather than to society and that the user, not the taxpayer, should pay for the privi- 
lege of higher education. Some supporters also believe that private universities will introduce international standards of competence and accountability. Fears that the emergence of private higher education will result in commercialization through the "purchasing" of degrees and development of a profit motive behind higher education have been somewhat tempered by important provisions in the Non-Governmental Universities Act.

The establishment of a private university requires the formation of a nonprofit corporation or foundation, with a board of trustees and a security deposit of about $\$ 250,000$ in an interest-bearing government account. Support has come mostly from generous individuals with a personal interest in education or with personal connections to trustees. These new private institutions are permitted by law to rent classroom and office space only for their first five years of operation, and must acquire deeded land for university development within that time limit. These requirements present a major challenge to institutions without additional capital, government land grants, or a major infusion of philanthropy.

\section{These private institutions have made a conscious effort to satisfy the demand for subjects that are perceived as highly remunerative in Bangladesh and there- fore popular with students-such as business administration, computer sci- ence, engineering, and medicine.}

The Act also mandates that 5 percent of all seats be reserved for "poor but meritorious" students, who are exempt from tuition charges. Such financial aid is intended to insure a minimum of diversity in the student body. Some of the new private universities, however, go beyond the minimum financial aid requirement. The Ahsanullah University of Science and Technology claims to offer a 50 percent tuition discount to an additional 5 percent of its students.

Many of these institutions would cease to function were it not for the generosity and dedication of the individuals who founded and work for them. The vice-chancellors of East West University and Central Women's University, both retired civil servants, work free of charge, as do many of the faculty and administrators at some of the private universities. A few private universities attract faculty by offering higher salaries than the public sector. However, the University Grants Commission (UGC), the higher education oversight body of the national government, finds the full-time teacher/student ratio to be alarmingly low at most of the private universities. Private institutions are forced to engage mostly part-time professors who are reluctant to leave the security of their full-time positions at public universities for risky private-sector jobs. As a result, a large number of retired professors can be found working as full-time faculty at the emerging private institutions.

While the 16 private universities exhibit a wide range of educational quality, they have many similarities. Most noteworthy is the universal adoption of the American model of higher education, with a four-year bachelor's degree, a credit-hour system, and an academic calendar patterned after that in the United States. Most of the private universities have tried to establish "links" with universities abroad, especially in the United States. The majority of these, however, are hollow credit transfer agreements. The driving force behind these arrangements appears to be the legitimization and prestige that often come with foreign academic associations, and the chance that international relationships will increase the likelihood of study abroad. However, some of the private universities, such as NSU, have had very successful experiences with visiting faculty from abroad. It will take these institutions time to establish truly productive cooperative relationships. One private institution in Dhaka, AMA International University, is a successful Philippine-Bangladesh joint venture with 330 students.

These private institutions have made a conscious effort to satisfy the demand for subjects that are perceived as highly remunerative in Bangladesh and therefore popular with students - such as business administration, computer science, engineering, and medicine. The sectarian institutions learned a hard lesson within their first years: religious studies do not attract the same numbers of full-fee students as do the sciences and business. Both Muslim universities have been forced to add more popular degree programs, including marketing and dentistry, to attract a wider number of students. The other private institutions are making efforts to appear innovative or specialized in addition to their mainstay course offerings. Several private universities are beginning programs in environmental studies, while still others are starting degrees in disaster management, physiotherapy, and textile engineering. Nearly all the private universities have started or will soon begin MBA programs of their own. The vice chancellors of the private universities give the universal impression that their institutions have created competition for the public universities, compelling Dhaka and Chittagong to begin offering similar programs or risk losing their popularity.

While the emergence of private universities may give public institutions pause in Bangladesh, the price of private tuition will likely limit any escalation in competition between the two sectors. Private universities are indeed complementary to the public system, but they are hardly a replacement for it. 